12 Kupferberg HJ, Burkhalter A, Way EL. A sensitive fluorimetric assay for morphine. Fed Proc 1963;22:249-55.

13 Ebert RV. The lung in congestive heart failure. Arch Intern Med 1961 ; 107:450-9.

14 Lappas DG, Geha D, Fischer JE, Laver MB, Lowenstein E. Filling pressures of the heart and pulmonary circulation of the patient with coronary artery disease after large intravenous doses of morphine. Anesthesiology 1975;42:153-9.

15 Moffitt EA, Tarhan S, Rudriguez R, Barnhorst DA, Pluth JR. Hemodynamic effects of morphine during and early after cardiac operations. Anesth Analg (Cleve) 1976;55:47-50.
16 Popio KA, Jackson DH, Ross AM, Schaeiner BF, Yu PN. Hemodynamic and respiratory effects of morphine and butorphanol. Clin Pharmacol Ther $1978 ; 23: 281-7$.

17 Flaim SF, Zelis R, Eisele JH. Differential effects of morphine on forearm blood flow: attenuation of sympathetic control of the cutaneous circulation. Clin Pharmacol Ther 1978;23:542-6.

18 Anonymous. Treatment for heart failure: stimulation or unloading? Lancet 1979 ;ii:777-9.

19 Goodman LS, Gilman A. The pharmacological basis of therapeutics. New York: Macmillan, 1975.

(Accepted 1 February 1980)

\title{
Cholestatic jaundice caused by cloxacillin: macrophage inhibition factor test in preventing rechallenge with hepatotoxic drugs
}

\section{RAFAEL ENAT, SIMON POLLACK, YEHUDITH BEN-ARIEH， ELLA LIVNI， DAVID BARZILAI}

\section{Summary and conclusions}

Severe intrahepatic cholestasis occurred in a patient after taking nitrofurantoin, ampicillin, and cloxacillin. As only nitrofurantoin was known to cause cholestasis she was given cloxacillin again two years later. The cholestasis reappeared at once. A macrophage inhibition factor test confirmed that cloxacillin was the offending drug.

Cloxacillin should be added to the growing list of drugs causing cholestasis. Inadvertent rechallenge with hepatototoxic drugs might be prevented by routine use of the macrophage inhibition factor test.

\section{Introduction}

Reports of unexpected hepatotoxicity of drugs are increasing. ${ }^{1-3}$ Penicillins, however, are rarely reported as causing liver damage, though transiently increased activities of serum aspartate and alanine transaminases (serum AST and serum ALT; SGOT and SGPT) and alkaline phosphatase have been recorded. ${ }^{4-16}$ Histologically proved anicteric hepatitis was reportedly induced by carbenicillin ${ }^{17}$ and oxacillin, ${ }^{18}$ and mild cholestasis occurred after oxacillin ${ }^{19}$ and phenoxymethylpenicillin. ${ }^{20}$ Oral penicillin also reportedly caused a chronic fluctuating cholestatic hepatitis. ${ }^{21}$

We report a case in which a second episode of severe cholestasis was shown by the macrophage inhibition factor test to have been caused by inadvertent rechallenge with cloxacillin. Hepatic damage by this drug, which is congeneric to oxacillin and differs from it only slightly, has not been reported before.

Rambam Medical Centre and Faculty of Medicine, Technion, Israel Institute of Technology, Haifa, Israel

RAFAEL ENAT, MD, senior lecturer in medicine

SIMON POLLACK, MD, lecturer in medicine

YEHUDITH BEN-ARIEH, MD, lecturer in pathology

DAVID BARZILAI, MD, professor of medicine and endocrinology

Beilinson Medical Centre, Petach Tiqva, Israel

ELLA LIVNI, PHD, head of drug allergy and autoimmunity unit

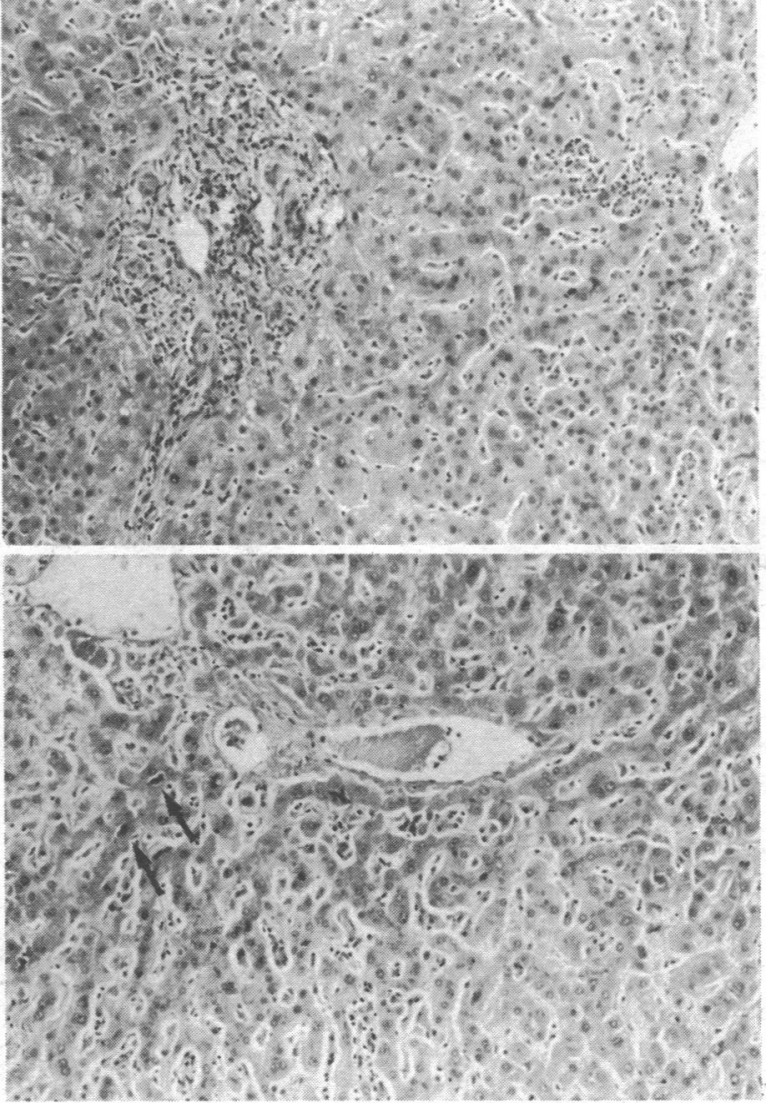

Light micrographs of wedge biopsy specimen of liver. Top: Portal space with round-cell infiltration and scattered liver cell necrosis. Bottom: Bile plugs in canaliculi (arrowed), swollen Kupffer cells, and evidence of anisocytosis. Haematoxylin and eosin $\times 100$ (original magnification).

\section{Case report}

A 69-year-old woman was admitted to hospital in 1976 with cholestatic jaundice. One month before she had been treated with nitrofurantoin for a urinary tract infection. Pneumonia was then suspected and she was given ampicillin and cloxacillin. Two weeks before admission she had begun to itch, and a few days later jaundice appeared.

On admission she had a normal temperature and showed signs of scratching all over her body. The liver was enlarged $3 \mathrm{~cm}$ below the costal margin and had a span of $15 \mathrm{~cm}$. The spleen was not palpable. Haemoglobin concentra- 
tion was $13.9 \mathrm{~g} / \mathrm{dl}$, white cell count $9 \times 10^{9} / 1\left(9000 / \mathrm{mm}^{3}\right.$; normal differential $)$ and erythrocyte sedimentation rate (Westergren) $26 \mathrm{~mm}$ in the first hour. Serum glucose, blood urea nitrogen, electrolyte, calcium, phosphate, protein, and cholesterol concentrations were normal, as were serum amylase activity and prothrombin time. Total serum bilirubin concentration was $255 \mu \mathrm{mol} / 1 \quad(14.9 \mathrm{mg} / 100 \mathrm{ml})$, direct value $164 \mu \mathrm{mol} / 1 \quad(9.6 \mathrm{mg} / 100 \mathrm{ml})$; serum AST activity $18 \mathrm{Gemsaec}$ units (normal $\leqslant 18$ units); and serum alkaline phosphatase activity 1126 Gemsaec units (normal $\leqslant 230$ units). Upper gastrointestinal tract examination, barium-enema examination, and a liver scan showed nothing abnormal. Ultrasound examination of the upper abdomen showed a normal gall bladder and no enlargement of the head of the pancreas. Intrahepatic echoes suggested either solid tumours or dilated bile ducts.

On the 13th hospital day liver needle biopsy showed intrahepatic cholestasis. The abnormal liver function values continued unchanged, and on the 24 th day laparotomy was performed. An enlarged, tense liver was seen. An intraoperative cholangiogram was normal. Wedge biopsy of liver showed slight focal fatty changes in the parenchyma and moderate lymphocytic infiltration of portal spaces with a few eosinophils (see figure: top). There was diffuse moderate to severe cholestasis (figure: bottom). A few scattered small foci of lymphocytes were seen at individual sites of necrosis (figure: top). Occasional slight anisocytosis was observed, some cells having several nuclei. Kupffer cells were swollen and contained lipofuscin and ceroid. No eosinophilic bodies or changes in bile ducts were detected. The diagnosis was a drug-induced hypersensitivity reaction, mainly cholestatic but with minor tissue-cell necrosis.

The patient was discharged 32 days after admission, and over the next two months liver function values returned to normal. Of the three drugs prescribed before admission, only nitrofurantoin was known to cause cholestasis ${ }^{22} 23$ : her condition was therefore attributed to that drug.

A few months after the jaundice had disappeared the patient was given ampicillin for a urinary tract infection. There were no side effects. In April 1978 she presented with an upper respiratory tract infection and was prescribed cloxacillin $2 \mathrm{~g}$ daily by mouth. Within four days she began to itch. One week later the total serum bilirubin concentration was $159 \mu \mathrm{mol} / 1$ $(9.3 \mathrm{mg} / 100 \mathrm{ml})$, direct value $84 \mu \mathrm{mol} / 1(4.9 \mathrm{mg} / 100 \mathrm{ml})$; serum AST activity 30 Gemsaec units; and alkaline phosphatase activity 676 Gemsaec units. The liver and spleen were not enlarged. A macrophage inhibition factor test confirmed hypersensitivity to cloxacillin. She was followed up as an outpatient, and during the first month the abnormal liver function values continued unchanged. Over the next two months values returned to normal.

\section{Methods and results}

The macrophage inhibition factor test was performed by the method of Rajapakse and Glynn ${ }^{24}$ as modified by Kuritzky et al. ${ }^{25}$ Ten elderly patients (three men and seven women) who had taken cloxacillin in the past without adverse effect served as controls. Samples of peripheral blood lymphocytes from the patient and each control were prepared separately and mixed with guinea-pig macrophages (ratio $1: 4$ ) in capillary tubes. These were placed in incubation chambers both with appropriate concentrations of cloxacillin and without cloxacillin. After 24 hours of incubation in $5 \% \mathrm{CO}_{2}$ at $37^{\circ} \mathrm{C}$ the area of migration of macrophages in the samples was calculated as the migration index - that is, area of migration with added drug/area of migration without drug. An index of 0.8 or less is taken as positive. Results in the controls were expressed as a mean.

In the absence of cloxacillin samples from both the patient and the controls showed a migration index of $1 \cdot 0$. Adding cloxacillin in concentrations of 50,100 , and $200 \mathrm{mg} / 1$, however, produced indices of 0.68 and $0.96,0.64$ and 0.92 , and 0.56 and 0.95 in samples from the patient and controls respectively.

\section{Comment}

Recurrent intrahepatic cholestasis rarely occurs as a benign idiopathic disease. Nevertheless, the clinical course and histological changes ${ }^{26}$ may be similar to those observed in our patient. The benign disease usually begins before the age of 30, though one patient was 59 at onset. ${ }^{27}$ The main differential diagnosis is cholestasis induced by drugs. In our patient cloxacillin was not suspected after the first episode of cholestasis, but the subsequent history and clinical and histological findings then suggested cloxacillin as the causative agent. This was confirmed by the macrophage inhibition factor test.

Patients are often prescribed several drugs simultaneously, some of which may be known to cause tissue damage. Thus if tissue damage occurs and is wrongly attributed to such a drug the patient may be inadvertently rechallenged with the toxic agent. We described a similar case $^{28}$ in which a patient was rechallenged with pyridinolcarbamate after an episode of liver damage that was assumed to have been caused by methyldopa.

The macrophage inhibition factor test is useful for identifying drugs causing hypersensitivity reactions. We therefore suggest that to prevent the risk of rechallenge with hepatotoxic drugs the test should be used in any patient showing signs of liver damage during multiple-drug treatment.

Requests for reprints should be addressed to: Dr Rafael Enat, Department of Internal Medicine C, Rambam Medical Centre, Haifa, Israel.

\section{References}

${ }^{1}$ Perez V, Schaffner F, Popper H. Hepatic drug reactions. Prog Liver Dis $1972 ; 4: 597-625$

2 Sherlock S. Diseases of the liver and biliary system. Oxford: Blackwell Scientific, 1975:340-82.

3 Zimmerman HJ. Liver disease caused by medicinal agents. Med Clin North Am 1975;59:897-907.

${ }^{4}$ Huang NN, Librenjak K, High RH. Therapeutic effect of oxacillin in patients with cystic fibrosis. Antimicrob Agents Chemother 1962;393-401.

5 Huang NN, Sproul A, Promadhattavedi V, High RN. Long-term therapy with oxacillin in patients with cystic fibrosis. Antimicrob Agents Chemother 1963;237-42.

6 Walker SH, Standiford WE. Treatment of infants with oxacillin sodium. Am f Dis Child 1967;114:64-8.

7 Nelson JD, Haltalin KC. Broad spectrum penicillins in enteric infections in children. Ann NY Acad Sci 1967;145:414-22.

${ }^{8} \mathrm{Neu} \mathrm{HC}$, Swarz H. Carbenicillin. Clinical and laboratory experience with a parenterally administered penicillin for treatment of pseudomonas infections. Ann Intern Med 1969;71:903-11.

${ }^{9}$ Boxerbaum B, Doershuk CF, Matthews LW. Use of carbenicillin in patients with cystic fibrosis. $\mathcal{F}$ Infect $D$ is $1970 ; 122$,suppl:59-61.

$10 \mathrm{Knirsch}$ AK, Gralla EJ. Abnormal serum transaminase levels after parenteral ampicillin and carbenicillin administration. $N$ Engl f Med 1970;282:1081-4.

11 Gump DW. Elevated SGOT levels after carbenicillin. $N$ Engl $f$ Med 1970;282:1489-90.

12 Bodey GP, Whitecar JP, Middleman E, Rodriguez V. Carbenicillin therapy for pseudomonas infections. $\mathcal{F} A M A 1971 ; 218: 62-6$.

13 Dismukes WE. Oxacillin-induced hepatic dysfunction. $\mathcal{F} A M A 1973 ; 226$ : 861-3.

${ }^{14}$ Klein I, Tobias H. Oxacillin-associated hepatitis. Am $\mathcal{F}$ Gastroenterol $1976 ; 65: 546-7$

15 Onorato IM, Axelrod JL. Hepatitis from intravenous high-dose oxacillin therapy. Findings in an adult inpatient population. Ann Intern Med $1978 ; 89: 497-500$.

${ }^{16}$ Pollock AA, Berger SA, Simberkoff MS, Rahal JJ Jr. Hepatitis associated with high-dose oxacillin therapy. Arch Intern Med 1978;138:915-7.

17 Wilson FM, Belamaric J, Lauter CB, Lerner AM. Anicteric carbenicillin hepatitis. Eight episodes in four patients. FAMA 1975 ;232:818-21.

${ }^{18}$ Bruckstein AH, Attia AA. Oxacillin hepatitis. Two patients with liver biopsy, and review of the literature. $A m \mathcal{F} M e d$ 1978;64:519-22.

19 Tenpas A, Quinn EL. Cholestatic hepatitis following the administration of sodium oxacillin. $\mathcal{F} A M A 1965 ; 191: 674-5$.

20 Goldstein LI, Ishak KG. Hepatic injury associated with penicillin therapy. Arch Pathol Lab Med 1974;98:114-7.

21 Girard JP, Haenni B, Bergoz R, Kapanci Y, Cruchaud A. Lupoid hepatitis following administration of penicillin. Case report and immunological studies. Helv Med Acta $1967 ; 34: 23-35$

${ }^{22}$ Ernaelsteen D, Williams R. Jaundice due to nitrofurantoin. Gastroenterology $1961 ; 41: 590-3$.

${ }^{23}$ Jokela S. Liver disease due to nitrofurantoin. Gastroenterology 1967;53 : 306-11.

${ }^{24}$ Rajapakse DA, Glynn LE. Macrophage migration inhibition test using guinea pig macrophages and human lymphocytes. Nature 1970;226: 857-8.

${ }^{25}$ Kuritzky A, Livni E, Munitz H, et al. Cell-mediated immunity to human myelin basic protein in schizophrenic patients. F Neurol Sci 1976;30: 369-73.

26 Sherlock S. Diseases of the liver and biliary system. Oxford: Blackwell Scientific, $1975: 284-99$.

27 Summerskill WHJ. The syndrome of benign recurrent cholestasis. $A m \mathcal{F}$ Med 1965;38:298-305.

${ }^{28}$ Enat R, Barzilai D, Gellei B. Hepatic injury due to pyridinolcarbamate. Isr $\mathcal{F}$ Med Sci 1978;14:333-8.

(Accepted 28 fanuary 1980) 